\title{
Towards Closure
}

Abstract How will societies emerge from the COVID-19 crisis? Will there be a reckoning with failing institutions and crisis leaders? Will valuable lessons be learned? These are the perennial questions that dominate the transitional phase between crisis and a new normal. In this chapter, we discuss how lessons from previous crises help to understand the many challenges that lie ahead of us.

Keywords COVID-19 · Public inquiries · Accountability · Learning · Crisis termination

Those who made mistakes will have to answer our questions and take on their own responsibilities. We ask for justice.-A grass roots movement set up by Italian COVID-19 survivors (Noi Denunceremo, 2020)

The only prediction about the future of politics that can be made with any certainty is that the 'COVID crisis' is sure to unleash an outbreak of divisive and disruptive political blame games as politicians, policymakers, advisers and experts all seek to avoid carrying the can for those decisions or opinions that inevitably turned out to be wrong. (Flinders, 2020)

There are plenty of things that people say and will say that we got wrong and we owe that discussion and that honesty to the tens of thousands 
who have died before their time.-Boris Johnson (quoted in Parker et al., 2020)

Even as we fight this pandemic, we must be readying ourselves for future global outbreaks and the many other challenges of our time such as antimicrobial resistance, inequality and the climate crisis. COVID-19 has taken so much from us. But it is also giving us an opportunity to break with the past and build back better.-WHO Director-General Tedros Adhanom Ghebreyesus (WHO, 2020)

\section{The Need for Closure}

It is hard to imagine as we write this, but one day the COVID-19 crisis will be over. Critics will have their say, as Prime Minister Boris Johnson and Professor Flinders predicted (see above). Calls for justice will be met by promises that lessons will be learned. The quotes above tell the story in a nutshell.

The pandemic will not disappear overnight. Pandemics fizzle out in a process of gradual domestication of a once mortal threat (Holmberg et al., 2017; McNeill, 1976; Rosenberg, 1992). This can happen through herd immunity or the development of an effective vaccine. We are lucky: an epic race between dozens of research universities and pharma labs has resulted in an almost unimaginably speedy process of vaccine delivery. Modern biomedicine has delivered the 'quick fix', compared to the much slower process leading to herd immunity.

But the large-scale societal crisis born from the pandemic will not simply fizzle out. Crisis closure is important for a society that wants to reach a point where it has learned to live with all facets of the crisis. Vaccines alone will not bring an end to the manifold economic, social, institutional and political conundrums the pandemic has caused. A crisis that is not effectively brought to a close can linger on for years if not decades (Boin et al., 2016).

Without effective closure of the crisis, fateful choices made during the crisis will continue to spark conflict. The central policy question of the crisis-how to protect human lives and at what economic and social costs to society as a whole?-has come into ever sharper relief as the crisis endured and expanded. The dilemma has pervaded cabinet, parliamentary and public deliberations in every country. Divisions have run deep. Referring the matter to 'experts' and relying on 'evidence' unsurprisingly 
have not helped overcome them. Every major spike in infections brought the conflict back in full force.

Traditionally, societies have evolved a suite of interrelated mechanisms to achieve crisis closure: rituals of accountability, learning and commemoration. In combination, and when performed in accordance with prevailing public expectations and social norms, these rituals facilitate a form of catharsis - an abatement of collective stress, a cooling down of political heat and a broad societal willingness to turn the page and move on.

\section{The Politics of Accountability}

The disaster sociologist Lee Clarke (1999) once observed that "crises, disasters and scandals result in public disquiet and in loss of confidence in the body of politics. Confidence can be effectively restored only by thoroughly investigating and establishing the truth and exposing the facts to public scrutiny" (p. 8). Before the COVID-19 crisis has come to an end, many scholars, advocates, NGOs and think tanks have already begun to analyse it. Official inquiries will focus on the causes of the pandemic and the responses to it. There likely will be series of detailed, revealing and often painful hearings. Victims will tell powerful stories of their suffering.

We can easily imagine that the following findings-in one shape or another-will emerge from these inquiries:

- We increased our vulnerability to viral pandemics by the way we organized our economies, our culture of leisure, our supply chains and our health systems.

- We allowed the pandemic to take us by surprise. Warning signals were ignored. Our risk perceptions and the state of emergency preparedness were clouded by an erroneous reliance on soothing historical analogies with 'near misses' - deadly viruses such as Ebola, SARS and HINl that were effectively prevented from escalating into global pandemics. These plans did not work for COVID-19.

- Institutional failures of imagination fed a sense of complacency with regard to the state of preparation for pandemics. The result: societies lacked elementary resources to combat the pandemic.

- The pandemic ruthlessly hit hardest those in already precarious positions. COVID-19 exposed entrenched inequalities in health, education, work, housing and well-being. 
- Government leaders found it hard to make uncomfortable decisions that required substantial sacrifices from large parts of the population.

- The first wave of the pandemic was characterized by a myopic and reactive response mode. We did too little to prepare our populations and systems for second waves, vaccination campaigns and post-pandemic innovation.

Crisis inquiries tend to follow a similar script: they reconstruct the course of events; describe pre-existing rules, structures, policies and responsibilities; establish who did what, when and how in both the lead up and the response to the crisis; offer causal interpretations; evaluate the performance of people, organizations, structures and processes; and make recommendations with regard to sanctions that should be meted out. Heroes and good practices will be identified and lauded. Policymakers will offer rationalizations. Apologies will be demanded (Boin et al., 2008; Lipsky \& Olson, 1977; Mintrom et al., 2020; Platt, 1971; Stark, 2018, 2019).

Governments do not always welcome such inquiries. It may take prodding, lobbying and looming reputational damage before an inquiry is initiated. In hard-hit Spain, for example, a group of doctors feared that no inquiry was forthcoming. They published an open letter to their government in the prominent medical journal The Lancet, "calling for an independent and impartial evaluation by a panel of international and national experts, focusing on the activities of the Central Government and of the governments of the 17 autonomous communities" (García-Basteiro et al., 2020). It was a deeply political act. Outsiders were to investigate Spaniards. Not just the health system was to be scrutinised but the 'social and economic circumstances'- a thinly veiled reference to a decade of austerity policies that had undermined Spain's pandemic preparedness.

Inquiries might provide a firm footing for learning. It could lead to a catharsis for traumatized victims and badly-shaken communities (think of the truth commissions in South Africa). But most crisis inquiries are, first and foremost, deeply political at heart. Their very design involves choices that are highly consequential and therefore highly contested. These choices pertain to the scope and aim of the inquiry, the people who will run it, the moment of delivery and the available resources. In their case study of the 9/11 Commission's work, Parker and Dekker (2008) offered the following observation: 
The 9/11 Commission was established only after a drawn-out political struggle. It was not until 14 months after the attacks on the Twin Towers and the Pentagon that an independent panel was established. The Bush administration, in particular, opposed the formation of an independent commission. It argued that a Congressional joint inquiry into the attacks was more than adequate and that an independent blue-ribbon commission was an unnecessary distraction from the war on terror. ... The families of the victims insisted that a broader inquiry was needed. Public pressure and an effective lobbying campaign persuaded enough House Republicans to join Democrats and produce a majority vote on 25 July 2002 to set up an independent commission. Still, the White House continued to resist... It took another two months of intense negotiations before the White House reached an agreement with Congress on the conditions under which the investigation would be conducted.... (pp. 266-269)

Critics will liken the accountability process to a 'blame game' and will accuse policymakers of blame avoidance. This frame can easily become an interpretive straightjacket that degrades the motives and actions of both account-givers and account-holders. With such a prism firmly in place, one might easily forget the broader functions of accountability and the essential standards by which we should assess its enactment (Bovens et al., 2008):

- Are democratically legitimized bodies able to monitor and evaluate executive behaviour?

- Can they induce executive actors to modify that behaviour in accordance with their preferences?

- Does accountability help to unearth and curtail the abuse of executive power and privilege?

- Does it help office-holders and organizations to effectively perform their public tasks (cf. Schillemans, 2016)?

In the charged context of a protracted mega-crisis such as COVID-19, it will not be easy to fulfil these functions. For one, the transboundary nature of this crisis is an ill fit for existing jurisdiction-based, sectorial response capacities (Boin, 2019). The policy environment for COVID-19 spans across multiple sectors of society, levels of government and indeed nation-state boundaries. As a result, it becomes difficult to pinpoint where 
responsibility lies, and therefore who are to be the relevant accountgivers-and by whom and how they ought to be held to account (Bovens, 1998).

Moreover, the intricate, uncertain and sometimes unprecedented nature of the pandemic makes it difficult to determine by what standards account-holders should assess the performance of office-holders, agencies, supply chains and networks prior to and during the pandemic. Also, given the ongoing nature of the COVID-19 crisis, account-holders struggle with the question of when to begin, how to pace and for how long to sustain accountability proceedings.

\section{Pressure and Opportunities}

Media, commentators and political scientists are often preoccupied with the question whether authority figures will lose their jobs as a result of accountability processes. This is understandable. The iron law of politics holds that when something bad has happened which is considered unacceptable, someone should (be forced to) 'take their responsibility'. That does not mean that those in charge of the crisis response will necessarily 'do the honourable thing' of their own accord (Sulitzeanu-Kenan, 2010).

When cruise ship The Ruby Princess arrived in New South Wales (NSW), Australia, in March 2020 with a few corona cases on board, it presented state health authorities with a first test of their pandemic preparedness. The inquiry into what happened next produced a blunt assessment (Special Commission of Inquiry, 2020, p. 32). But the NSW Health staff and the responsible minister all kept their jobs. The latter's colleague in the bordering state of Victoria was not so lucky: when it transpired that mismanagement of hotel quarantine supervision had been at the heart of that state's big and lethal 'second wave', Health Minister Jenny Mikakos and several top bureaucrats were forced to resign (cf. The Board of Inquiry, 2020).

An internal review into the breakdown of quarantine arrangements that led to the reintroduction of corona into COVID-free New Zealand, conducted at lightning speed by three experienced hands, was equally blunt about ministerial performance. It called a spade a spade. The health minister was sacked by the same prime minister, Jacinda Ardern, who would go on to win the election four months later in spectacular fashion (Menon, 2020; Roy, 2020). 
This is how accountability unfolds during and after crises: intense discussions about who bears responsibility for what has occurred and what, if any, consequences should flow from these assessments. In times of crises, accountability processes are supposed to bring clarity, facilitate performance assessment, guide sanctioning and contribute to closure.

In spite of valiant attempts, researchers find it hard to predict how accountability rituals will unfold and whether they will serve their social function of extinguishing the flames of collective stress (Boin et al., 2008; Bovens et al., 1999; Hinterleitner \& Sager, 2015; Hood et al., 2016; Resodihardjo et al., 2016). But we do know which factors matter in shaping the outcome. Much depends on institutional context, timing, the presence or absence of distractions and scapegoats, and the ever-evolving political calculus of key authority figures. Political capital is another important factor: office-holders enter a crisis with variable reputations and 'credit' as shaped by their prior performances and their level of centrality in the ruling government's power edifice (Brändström, 2016; De Ruiter, 2019; Kuipers \& Brändström, 2020; Resodihardjo, 2020).

\section{Effects of the Accountability Process}

The accountability process can have a profound effect on the public's perception of the political system. As the accountability spectacle unfolds, people make up their minds about politicians, institutions and 'the system' (cf. Christensen \& Aars, 2019). Not having accountability rituals at all, or being seen to obstruct them, renders them toothless. This will not endear crisis leaders to citizens, particularly those groups who were put at risk or suffered in the course of the crisis. More importantly, it will affect democratic legitimacy. Hilliard et al. (2020) explain why:

Public demands to diagnose what went wrong and to hold those responsible to account dominate public debates, constraining the range of policy responses available to political elites. In theory, this process is crucial for the restoration of trust between state and society. An over-emphasis on policies of accountability, however, makes negotiations among political parties adversarial, confrontational, and often punitive, limiting the prospect of harmonious decision making and precluding the consensus needed for effective reform. In times of crisis, demagogues ride the tide of popular discontent and hijack calls for accountability to play the blame game against opponents, further trimming democratic legitimacy. (p. 14) 
Accountability is especially important in systems where it is not firmly established or is being eroded. In systems where the executive has involved a logic of 'crisis government' to 'grab power' on the wings of the pandemic, crisis closure may not occur through due diligence in performing accountability rituals. When leaders try to achieve closure through issuing directives, telling their subjects that things have gone back to normal while sweeping hard questions about their own conduct under the carpet, trust in the accountability process will quickly erode (cf. Edelman, 1971; Linz \& Stepan, 1978; Rossiter, 1948).

Astute politicians understand the importance of performing accountability rituals. These rituals differ per society. In some accountability forums, combative forms of engagement may be allowed or even expected. In others, the script dictates respectful, deferential, open and curious engagement with independent inquiries.

Some parliaments have either been semi-suspended or have decided to give a wide berth to governments during the COVID-19 crisis, thereby postponing the accountability work; others have been highly assertive and have demanded ongoing engagement from government. For example, in a discussion of the Czech Republic during the first phase of the epidemic, Guasti (2020) observes that:

while the Czech government occasionally swerves towards illiberalism, political opposition, media and courts provide an effective bulwark against the rise of autocracy. Czech civil society, universities, and startups were able to mitigate the scarcity of PPE effectively. Investigative journalists provided information about gaps in the pandemic response. Political opposition unified and held the government accountable. The parliament functions as an effective check by rejecting the indefinite state of emergency. The courts ensure that the pandemic response does not undermine democracy and the rule of law. (p. 55)

In some other European countries, the rule of law and the fabric of monitory democracy were not so resilient (Lührmann et al., 2020). Countries where these violations have been most visible were the ones where democracy had been 'back sliding' prior to the pandemic, notably Hungary and Poland. Concerns about authoritarian 'power grabs' during the first months of the pandemic ran so high that a group of 500 luminaries including Nobel laureates, former heads of governments, judges and 
dozens of NGOs issued a collective 'Call to defend democracy'. They observed that:

Authoritarian regimes, not surprisingly, are using the crisis to silence critics and tighten their political grip. But even some democratically elected governments are fighting the pandemic by amassing emergency powers that restrict human rights and enhance state surveillance without regard to legal constraints, parliamentary oversight, or time frames for the restoration of constitutional order. Parliaments are being sidelined, journalists are being arrested and harassed, minorities are being scapegoated, and the most vulnerable sectors of the population face alarming new dangers as the economic lockdowns ravage the very fabric of societies everywhere. (Call to Defend Democracy, 2020)

\section{The Politics of Learning}

Crises are great teachers for those who are willing to learn (Derwort et al., 2018; Newig et al., 2019). They create opportunities for those who seek to shatter bastions of convention ('the way we do things around here') and open space for hitherto silenced voices, unpopular ideas, untried policies and new institutions (Hay, 1996).

Research findings do not support the often-heard stereotype that crisis inquiries are primarily symbolic 'pressure valves'. In fact, post-crisis inquiries appear to be quite effective mechanisms for learning about crises (Stark, 2018, 2019). The 9/11 Commission's final report, for instance, proved catalytic for reform of the byzantine and distinctly un-collegiate US intelligence community. Likewise, Mintrom et al. (2020) find that Royal Commissions can have positive impacts if they succeed in careful narrative framing, coalition-building and stress-testing to ensure their recommendations are implementable.

This brings us to the challenge of recovery and renewal: how a society can move on after crisis without suffering for a long time from its legacy. The question is whether a society chooses to learn the lessons that will help to move it forward in a stronger fashion. The pandemic has revealed gaps in the resilience of healthcare and emergency management systems. It has exposed the downsides of the 'just-in-time' and 'as cheap as possible' logic of globalized supply chains for pharmaceutical products and critical medical equipment. It exacerbated social disadvantages by hitting hardest those already in the low-paid gig industry, the 
long-term unemployed, children locked in precarious family settings and people experiencing disability or chronic health issues.

The pandemic also revealed the strengths of systems, organizations and people, whether it be manufacturing corporations rapidly adjusting their production to meet urgent needs for protective equipment, the remarkable scale and pace of self-organizing community support for elderly and vulnerable citizens, public agencies stepping up to work at breakneck speed and in unusual unison, or governments willing to adopt a bi-partisan and explicitly evidence-based approach to policymaking.

Virologists, epidemiologists and other medical specialists scrambled to find out what they were dealing with, sharing emerging insights about the virus, its impacts and treatment options at frenetic pace. Governments and public health providers built capacities for testing, contact tracing and running quarantines - none of which proceeded without high-profile errors, which, in turn, became subjects of intense scrutiny, and considerable real-time adaptation (Mazey \& Richardson, 2020, p. 5). Schools, hospitals, nursing homes, prisons, human services providers, retail stores, internet providers, transport firms, the hospitality industry: all had to adjust their operating models to lockdowns, border closures, infection clusters-and then to government support schemes and regulatory interventions.

At the policy level, learning proved more challenging and contested. Senior policymakers had to learn how their goals could best be met and at what price. In some countries, swift changes to initial strategies were adopted in the light of emerging data and feedback; in others, policymakers persevered with their initial choice while resisting heavy pressure to change tack. The contrasting cases of New Zealand (adhocratic policy learning on-the-hop) and Sweden (policy persistence despite negative feedback and public controversy) provide textbook examples of these different intracrisis learning dynamics (Stern, 2015). Both were performed with conviction and flair, and seemed to resonate well with majority public sentiments in the two countries, but neither proved flawless or incontestable.

From the very beginning of the crisis, a rhetoric of learning emerged, emphasizing the need to distil lessons. What those lessons ought to be is of course anything but self-evident. Nor can it be taken for granted that high-minded commitments to implement recommendations of inquiries are matched by vigorous and sustained efforts to do so. Change may well occur, but not necessarily as a product of learning (Schiffino et al., 2015). 
Reaching beyond the crisis response issues, governments at all levels, international organizations, think tanks as well as advocates for innovation and reform in various policy domains have already begun to stake out the terrain and articulate their visions of recovery, proposing alternative futures (see, for instance, Dawson \& McCalman, 2020). So have 'pandemic populists' of the far right, and conspiracy theorists who seek to expose and crush the deep state, big tech and critics of liberal democracy (Vieten, 2020).

What all such proponents of 'recovery' and 'change' have in common is that they seek to exploit the surge in attention, the rattled mindsets, the pent-up emotions, the policy vacuums, the political uncertainty and the plentiful debates, to dramatize the need for their version of 'change'. COVID-19 appears to provide everyone with a chance to see what they want to see, and to argue for policy shifts they had been advocating for some time. Advocates for big government, for instance, point to the lack of foresight in pandemic preparedness, which has forced governments into reactive, improvisational fire-fighting:

Covid-19 might possibly turn out to have been a seismic event in the process by which public policies are made. [It] has demonstrated beyond doubt that when the going gets tough, the public relies on governments, not markets, to come to the rescue... It has taken one virus to kill another. Fiscal constraint, prudence, and 'good housekeeping' rules that since the 1980s framed and severely constrained debates about what is or is not possible across almost every policy sector (and across national boundaries) now look very outdated. (Mazey \& Richardson, 2020, p. 8)

Some choose the language of evidence to remind their audiences of the need for equity-enhancing policy shifts:

We know infectious diseases, like other health conditions, are highly influenced by the social determinants of health. That is, the conditions in which people live, learn and work, play a significant role in influencing their health outcomes. Broadly speaking, the greater a person's socioeconomic disadvantage, the poorer their health. In shining a light on these inequities the pandemic also provides an opportunity for us to begin to address them, which will have both short and longer term health benefits. (Vally, 2020)

But every push for crisis-induced 'lesson-drawing' that involves shaking up entrenched institutions, and the beliefs and interests of the coalitions 
underpinning them, elicits a counter push. The defenders of the status quo employ a version of what Hirschman (1991) called the rhetoric of reaction: that the system really isn't broken, that the proposed solutions are futile or even worse than the maladies of the present order, that their introduction will only create confusion and chaos.

\section{Learning Barriers}

It is difficult to learn in a well-considered and balanced way from crisis episodes (cf. Bovens \& 't Hart, 1996; Stern, 1999). First, the dominant narrative about how the crisis came about may be skewed by hindsight bias, or by an overemphasis on the choices and actions of a limited number of individuals while ignoring broader structural factors, let alone the role of contingency and chance (An \& Tang, 2020). The diagnostic work of inquiries - often key drivers of generating lessons-may be compromised by its members putting the pursuit of 'pet theories' above careful consideration of all the evidence, as well as by the imposition of strict deadlines, constrained mandates and paltry budgets (Boin, 2008; Parker \& Dekker, 2008).

Second, there is the 'recency' bias. The typical crisis-induced learning effort adopts an $N=1$ approach: deep immersion into the crisis of the hour, more often than not at the expense of a comparative, longitudinal, multi-N approach that provides a more robust and broader evidence base. Crisis inquiries tend to entrench a single set of experiences packaged into a single historical analogy. This can become so dominant within the inquiry's collective memory and mindset that it unwittingly gears itself up to fight the last war-only the last war, and only a particular version of it.

Third, there is the political psychology of crisis learning, which tends to skew receptivity towards the firm and the dramatic, and away from the ambiguous and the subtle. Rocked by disturbing experiences, we are motivated to learn more what feels good (and what satisfies our felt need for decisive action) than what a more dispassionate analysis would suggest makes the most sense. De Bruin and Van der Steen (2020, own translation) put it aptly:

The deeper the crisis, the bigger the societal demand for unequivocal accounts and lessons. When a crisis has produced massive damage and much suffering, we generally become less interested in explanatory nuances and prefer clarity above all. The more unambiguous the explanations, the 
more these can be peppered with terms such as 'sharp', 'clear', 'tough' and 'rigorous'. The same goes for the lessons that are being put forward: things need to become altogether and radically different. It is language that feels good when we are rattled by a crisis. This results in a strange paradox: the more complex and comprehensive a crisis has become, the greater the need for competing perspectives on it, and yet at the same time the greater the expected intolerance for such contestability and nuance in lesson-drawing. (p. 12)

Fourth, implementing lessons may well entail the changing of beliefs, structures, systems, staff, procedures or even cultures. None of that comes cheap or easy; it is always risky. Organizations often prove much more adept and willing to learn incremental, cheap and technical lessons. There is less of an inclination to seek learning at the deeper and more strategic level of the beliefs, values and cultures that underpin and sustain their policies and practices.

Even when faced with damning inquiries and heavy pressure to prevent repetition of a recent traumatic event, policymakers do not stop having to make decisions under uncertainty, facing competing demands and limited resources. Some of those decisions may work at cross-purposes of their avowed commitment to 'learn the lessons' of the crisis. Lee et al. (2020) offer a good example:

In 2005, BP experienced a major accident in its Texas City refinery that killed 15 people. This was followed in 2006 by a five-day leak in the BP pipeline that released the largest amount of oil in the history of Alaska. In 2010, BP Deepwater Horizon exploded, killing 11 people and spilling close to five million barrels of oil into the Gulf of Mexico. From each accident, BP learned to improve safety, first in refining and then in pipeline operations. However, the learning was myopic and confined to specific divisions: refining and pipeline operations. BP did not [accept] that it had a deeper problem with a culture that sacrificed safety for profit. By the time BP confronted the Deepwater Horizon oil platform disaster, it was too late. (p. 1037)

How contending diagnoses of past crises and visions for post-crisis futures ultimately translate into institutional learning and purposeful change varies markedly. Most research on the matter suggests we should expect piecemeal rather than dramatic policy change (Boin et al., 2008; Keeler, 
1993). Even when crises hand rare windows of opportunity to advocates of reform, they need to play their cards very carefully. They run considerable political risk if they seek to capitalize on the momentum (Berman, 2020; Boin et al., 2009; Goldfinch \& 't Hart, 2003; Hogan \& Feeney, 2012; Keeler, 1993). Agile status-quo coalitions can manoeuvre to neutralize crisis-driven reform agendas (Cortell \& Peterson, 1999; Nohrstedt \& Weible, 2010; Pierson, 2005).

\section{COVID's Long Shadow And the Politics of Memory}

The COVID-19 pandemic will cast a long shadow on hard-hit families, communities, regions, professions, industries and nations. It will be remembered as a marker of our times, perhaps as a symbol of our vulnerability or indeed our resilience. People will develop rituals of remembrance and mourning. The catastrophe will make its way into songs, poems, novels, documentaries, history books, just as '1956' did in Hungary (Nyssönen, 1999), major floods did in Dutch cultural memory (Jensen, 2018), and Vietnam (Eyerman, 2019), Watergate (Schudson, 1993) and ' $9 / 11$ ' (Bond, 2015) did in the US.

While not necessarily overtly political in how these memories are constituted and modified over time, these processes are deeply political in their consequences. These memories affirm or criticize past choices, and shape perceptions of crisis leaders and the institutions that implemented their policies. They separate the good from the bad, suggesting what communities, professions and politicians should do and not do in regard to future crises. They determine not just what we remember, but also what we choose to forget.

Stories about the pandemic's occurrence will be told, retold and challenged. There will be stories about the hubris of our leaders ignoring the warnings of experts (Snowden, 2020). Stories about the pandemic as an inevitable by-product of the complex and tightly interconnected systems that have been deeply integrated into our way of life, and the cultural normalization of the risk of cascading failures that comes with it (cf. Perrow, 1999; Tomaskovic-Devey, 2020). Stories that explain how the pandemic and the responses to it ended up changing our societies profoundly-or not changing them in spite of all the damage and suffering that was inflicted.

These and many other crisis stories will co-exist in collective memory. They will be fought over. They will be resurrected, forgotten, twisted 
and turned, and selectively applied to interpret future epidemiological challenges and the governance of health and disease. Historians, media, history books, teachers, politicians, interest groups will accentuate some version and background others. 'Forgotten' perspectives on the crises will be unearthed and advocated. Like 'Munich' or 'Swine Flu', 'COVID-19' will become condensed and repackaged as a set of historical analogies that will impinge themselves upon the sense-making and decision-making of future policymakers and crisis responders (Beach et al., 2019; Brändström et al., 2004; Khong, 1992; Neustadt \& May, 1986).

Like the Holocaust, the Vietnam War, the life and death of Communism and 9/11, COVID-19 has turned big enough and bad enough for its history to be written and rewritten, remembered and forgotten, leveraged and abused for a very long time (Eril, 2020). In that sense, the politics of the pandemic and the crisis it created will not come to an end any time soon.

\section{BIBLIOGRAPHY}

An, B. Y., \& Tang, S. Y. (2020). Lessons from COVID-19 responses in East Asia: Institutional infrastructure and enduring policy instruments. American Review of Public Administration, 50(6-7), 790-800.

Beach, D., Schäfer, D., \& Smeets, S. (2019). The past in the present: The role of analogical reasoning in epistemic learning about how to tackle complex policy problems. Policy Studies Journal. https://doi.org/10.1111/psj.12372.

Berman, S. (2020, July 4). Crises only sometimes lead to change. Here's why. Foreign Policy. https://foreignpolicy.com/2020/07/04/coronavirus-cri sis-turning-point-change/.

Boin, A. (2008). Learning from crisis: NASA and the Challenger disaster. In A. Boin, A. McConnell, \& P. 't Hart (Eds.), Governing after crisis: The politics of investigation, accountability and learning (pp. 232-254). Cambridge University Press.

Boin, A. (2019). The transboundary crisis: Why we are unprepared and the road ahead. Journal of Contingencies and Crisis Management, 27(1): 94-99.

Boin, A., 't Hart, P., \& McConnell, A. (2009). Crisis exploitation: Political and policy impacts of framing contests. Journal of European Public Policy, 16(1), 81-106.

Boin, A., 't Hart, P., Stern, E., \& Sundelius, B. (2016). The politics of crisis management. Cambridge University Press.

Boin, A., McConnell, A., \& 't Hart, P. (Eds.). (2008). Governing after crisis: The politics of investigation, accountability and learning. Cambridge University Press. 
Bond, L. (2015). Frames of memory after 9/11. Palgrave.

Bovens, M. A. P. (1998). The quest for responsibility: Accountability and citizenship in complex organisations. Cambridge university press.

Bovens, M., \& 't Hart, P. (1996). Understanding policy fiascos. Transaction Publishers.

Bovens, M., 't Hart, P., Dekker, S., \& Verheuvel, G. (1999). The politics of blame avoidance: Defensive tactics in a Dutch crime-fighting scenario. In H. K. Anheier (Ed.), When things go wrong: Organizational failures and breakdowns (pp. 123-147). Sage.

Bovens, M., Schillemans, T., \& 't Hart, P. (2008). Does public accountability work? An assessment tool. Public Administration, 86(1), 225-242.

Brändström, A. (2016). Crisis, accountability and blame management: Strategies and survival of political office-Holders (Doctoral dissertation, Utrecht University, Utrecht University Repository). http://dspace.library.uu.nl/han dle/1874/324946.

Brändström, A., Bynander, F., \& 't Hart, P. (2004). Governing by looking back: Historical analogies and crisis management. Public Administration, 82(1), 191-210.

Call to Defend Democracy. (2020, June 25). A Call to Defend Democracy. International IDEA. https://www.idea.int/news-media/multimedia-reports/calldefend-democracy.

Christensen, D. A., \& Aars, J. (2019). The July 22 terrorist attacks in Norway: Impact on public attitudes towards counterterrorist authorities. Scandinavian Political Studies, 40(3), 312-329.

Clarke, L. (1999). Mission improbable: Using fantasy documents to tame disaster. University of Chicago Press.

Cortell, A., \& Peterson, S. (1999). Altered states: Explaining domestic institutional change. British Journal of Political Science, 29(1), 177-203.

Dawson, E., \& McCalman, J. (Eds.). (2020). What happens next? Reconstructing Australia after Covid-19. Melbourne University Press.

De Bruin, J., \& Van der Steen, M. (2020). Leren van Covid-19. NSOB.

De Ruiter, M. (2019). Walking the tightrope: Political accountability, blame, and ministerial survival in two parliamentary systems (Doctoral dissertation, Utrecht University, Utrecht University Repository). https://dspace.library.uu. $\mathrm{nl} /$ handle/1874/378725.

Derwort, P., Jager, N., \& Newig, J. (2018). Towards productive functions? A systematic review of institutional failure, its causes and consequences. Policy Sciences, 52(2), 281-298.

Edelman, M. (1971). Politics as symbolic action: Mass arousal and quiescence. Academic Press.

Eril, A. (2020). Afterword: Memory worlds in times of Corona. Memory Studies, $13(5), 861-874$. 
Eyerman, R. (2019). Memory, trauma, and identity. Springer.

Flinders, M. (2020). Gotcha! Corona Virus, crises and the politics of blame games. Political Insight, 11(2), 22-25.

García-Basteiro, A., Alvarez-Dardet, C., Arenas, A., Bengoa, R., Borrell, C., Del Val, M., Franco, M., Gea-Sánchez, M., Otero, J. J. G., Valcárcel, B. G. L., Hernández, I., March, J. C., Martin-Moreno, J. M., Menéndez, C., Minué, S., Muntaner, C., Porta, M., Prieto-Alhambra, D., Vives-Cases, C., \& LegidoQuigley, H. (2020). The need for an independent evaluation of the Covid-19 response in Spain. The Lancet, 396(10250), 529-530.

Goldfinch, S., \& 't Hart, P. (2003). Leadership and institutional reform: Engineering macro-economic policy change in Australia. Governance, 16(2), $235-270$.

Guasti, P. (2020). The impact of the Covid-19 pandemic in Central and Eastern Europe: The rise of autocracy and democratic resilience. Democratic Theory, $7(2), 47-60$.

Hay, C. (1996). Narrating crisis: The discursive construction of the 'winter of discontent'. Sociology, 30(2), 253-277.

Hilliard, N., Kovras, I., \& Loizides, N. (2020). The perils of accountability after crisis: Ambiguity, policy legacies, and value trade-Offs. Cambridge Review of International Affairs. https://doi.org/10.1080/09557571.2019.1710827.

Hinterleitner, M., \& Sager, F. (2015). Avoiding blame-A comprehensive framework and the Australian home insulation program fiasco. The Policy Studies Journal, 43(1), 139-161.

Hirschman, A. O. (1991). The rhetoric of reaction: Perversity, futility, jeopardy. Harvard University Press.

Hogan, J., \& Feeney, S. (2012). Crisis and policy change: The role of the political entrepreneur. Risk, Hazards \& Crisis in Public Policy, 3(2), 1-24.

Holmberg, C., Blume, S., \& Greenough, P. (2017). The politics of vaccination: A global history. Manchester University Press.

Hood, C., Jennings, W., \& Copeland, P. (2016). Blame avoidance in comparative perspective: Reactivity, staged retreat and efficacy. Public Administration, 94(2), 542-562.

Jensen, L. (2018). Wij tegen het water: Een eeuwenoude strijd. Van Tilt.

Keeler, J. (1993). Opening the window for reform: Mandates, crises, and extraordinary policy-making. Comparative Political Studies, 25(1), 433-486.

Khong, Y. F. (1992). Analogies at war. Princeton University Press.

Kuipers, S., \& Brändström, A. (2020). Accountability and blame avoidance after crisis. Oxford Research Encyclopaedia of Politics. https://doi.org/10.1093/acr efore/9780190228637.013.1498.

Lee, G., Lampel, J., \& Shapira, Z. (2020). After the storm has passed: Translating crisis experience into useful knowledge. Organization Science, 31(4), 10371051. 
Linz, J., \& Stepan, A. (1978). The breakdown of democratic regimes. Johns Hopkins University Press.

Lipsky, M., \& Olson, D. (1977). Commission politics: The processing of racial crisis in America. Transaction.

Lührmann, A., Edgell, A., Grahn, S., Lachapelle, J., \& Maerz, S. (2020). Does the Corona virus endanger democracy in Europe? Carnegie Europe. https:// carnegieeurope.eu/2020/06/23/does-coronavirus-endanger-democracy-ineurope-pub-82110.

Mazey, S., \& Richardson, J. (2020). Lesson-drawing from New Zealand and Covid-19: The need for anticipatory policy making. The Political Quarterly, 91(3), 561-570.

McNeill, W. H. (1976). Plagues and peoples. New York: Norton.

Menon, P. (2020, October 16). New Zealand's Ardern wins 'historic' re-election for crushing COVID-19. Reuters. https://www.reuters.com/article/us-new zealand-election/ardern-wins-landslide-re-election-in-new-zealand-vote-idU SKBN2712ZE.

Mintrom, M., O’Neill, D., \& O'Connor, R. (2020). Royal commissions and policy influence. Australian Journal of Public Administration. https://doi. org/10.1111/1467-8500.12441.

Neustadt, R., \& May, E. R. (1986). Thinking in time: The uses of history for decisionmakers. Free Press.

Newig, J., Derwort, P., \& Jager, N. (2019). Sustainability through institutional failure and decline? Archetypes of productive pathways. Ecology and Society, 24(1), 18 .

Nohrstedt, D., \& Weible, C. M. (2010). The logic of policy change after crisis. Risks, Hazards and Crises in Public Policy, 1(2), 1-32.

Noi Denunceremo. (2020). Noi Denunceremo - Verità e giustizia per le vittime di Covid-19. https://www.noidenunceremo.it/.

Nyssönen, H. (1999). The presence of the past in politics: '1956' after 1956 in Hungary. SoPhi.

Parker, G., Cookson, C., Neville, S., Payne, S., Hodgson, C., Gross A., \& Hughes, L. (2020, July 16). Inside Westminster's coronavirus blame game. Financial Times. https://www.ft.com/content/aa53173b-eb39-4055-b112000lclf6delb.

Parker, C., \& Dekker, S. (2008). September 11 and postcrisis investigation: Exploring the role and impact of the 9/11 Commission. In A. Boin, A. McConnell, \& P. 't Hart (Eds.), Governing after crises: The politics of investigation, accountability, and learning (pp. 255-282). Cambridge University Press.

Perrow, C. (1999). Organizing to reduce the vulnerabilities of complexity. Journal of Contingencies and Crisis Management, 7(3), 150-155.

Pierson, P. (2005). Politics in time. Princeton University Press. 
Platt, A. (1971). The politics of riot commissions. Collier.

Resodihardjo, S. (2020). Crises, inquiries and the politics of blame. Palgrave Macmillan.

Resodihardjo, S. L., Carroll, B. J., Van Eijk, C. J. A., \& Maris, S. (2016). Why traditional responses to blame games fail: The importance of context, rituals, and sub-blame games in the face of raves gone wrong. Public Administration, 94(2), 350-363.

Rosenberg, C. (1992). Explaining epidemics. Cambridge University Press.

Rossiter, C. L. (1948). Constitutional dictatorship: Crisis government in the modern democracies. Princeton University Press.

Roy, E. A. (2020, July 2). New Zealand health minister David Clark quits over handling of Covid-19 outbreak. The Guardian. https://www.theguardian. com/world/2020/jul/02/new-zealand-health-minister-david-clark-quitsover-handling-of-covid-19-outbreak.

Schiffino, N., Taskin, L., Donis, C., \& Raone, J. (Eds.). (2015). Organizing after crisis: The challenge of learning. Peter Lang.

Schillemans, T. (2016). Calibrating public sector accountability. Public Management Review, 18(9), 1400-1420.

Schudson, M. (1993). Watergate in American memory: How we remember, forget, and reconstruct the past. Basic Books.

Snowden, F. M. (2020). Epidemics and society. Yale University Press.

Special Commission of Inquiry into the Ruby Princess. (2020). Report of the special commission of inquiry into the Ruby Princess. New South Wales Government. https://www.nsw.gov.au/covid-19/special-commissionof-inquiry-ruby-princess.

Stark, A. (2018). Public inquiries, policy learning, and the threat of future crises. Oxford University Press.

Stark, A. (2019). Policy learning and the public inquiry. Policy Sciences, 52(3), $397-417$.

Stern, E. (1999). Crisis and learning: A conceptual balance sheet. Journal of Contingencies and Crisis Management, 5(2), 69-86.

Stern, E. (2015). Bridging the crisis-learning gap: From theory to practice. In M. Schiffino, L. Taskin, C. Donis, \& J. Raone (Eds.), Organizing after crisis: The challenge of learning (pp. 257-278). Peter Lang.

Sulitzeanu-Kenan, R. (2010). Reflection in the shadow of blame: When do politicians appoint commissions of inquiry? British Journal of Political Science, $40(3), 613-634$.

The Board of Inquiry. (2020). COVID-19 hotel quarantine inquiry. Victorian Government. https://www.quarantineinquiry.vic.gov.au/.

Tomaskovic-Devey, D. (2020). The Covid 19 pandemic: Normal accidents and cascading system failures. Footnotes, 48(3), 26-27. 
Vally, H. (2020, July 28). Social housing, aged care and Black Americans: How coronavirus affects already disadvantaged groups. The Conversation. https://theconversation.com/social-housing-aged-care-and-black-ame ricans-how-coronavirus-affects-already-disadvantaged-groups-142046.

Vieten, U. (2020). The "new normal" and "pandemic populism": The COVID19 crisis and anti-hygienic mobilisation of the far-right. Social Sciences, 9(9), 165.

World Health Organization (WHO). (2020, July 9). WHO Director-General opening remarks at the Member State Briefing on the COVID-19 pandemic evaluation [Speech]. https://www.who.int/director-general/speeches/det ail/who-director-general-opening-remarks-at-the-member-state-briefing-onthe-covid-19-pandemic-evaluation-9-july-2020.

Open Access This chapter is licensed under the terms of the Creative Commons Attribution 4.0 International License (http://creativecommons.org/licenses/ by $/ 4.0 /)$, which permits use, sharing, adaptation, distribution and reproduction in any medium or format, as long as you give appropriate credit to the original author(s) and the source, provide a link to the Creative Commons license and indicate if changes were made.

The images or other third party material in this chapter are included in the chapter's Creative Commons license, unless indicated otherwise in a credit line to the material. If material is not included in the chapter's Creative Commons license and your intended use is not permitted by statutory regulation or exceeds the permitted use, you will need to obtain permission directly from the copyright holder.

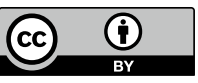

